\title{
Rancang Bangun Sistem Informasi Praktik Kerja Lapangan Pada Program Studi Teknik Informatika Universitas Mataram Menggunakan Extreme Programming
}

\author{
(Design of Field Study Information System at Department of Informatics \\ Engineering University of Mataram using Extreme Programming)
}

\author{
Mohammad Zaenuddin H, Sri Endang Anjarwani, I Wayan Agus Arimbawa \\ Program Studi Teknik Informatika, Fakultas Teknik, Universitas Mataram \\ Jl. Majapahit No 62 Mataram, Lombok, NTB-INDONESIA \\ Email: mzaenuddinhamidi@gmail.com, endang@unram.ac.id, arimbawa@unram.ac.id
}

\begin{abstract}
The development of information technology and information system recently make almost all aspects of life cannot avoid the use of computers. Job training is an obligatory unit taken by the entire students of Information and Technology program (PSTI) at faculty of Engineering Mataram University. The administration process of job training in PSTI is done manually. The development method used to build this information system was extreme programming, which emphasized system development in brief time scale, productivity, flexibility, and teamwork. Extreme programming used iteration during development processes that included planning, designing, programming, coding and testing. In testing process, the researcher used User Acceptance Test which is a testing process to complete the developed system to be accepted by users.
\end{abstract}

Keywords: Information system, Extreme Programming, Job Training

\section{PENDAHULUAN}

Salah satu kebutuhan yang sangat besar akan teknologi informasi sekarang ini adalah kebutuhan akan sistem informasi. Berkembangnya teknologi informasi dan sistem informasi yang demikian pesat di era sekarang ini telah membuat hampir semua aspek kehidupan tidak dapat terhindar dari penggunaan perangkat komputer.

Praktik Kerja Lapangan (PKL) merupakan salah satu mata kuliah yang wajib ditempuh oleh seluruh mahasiswa Program Studi Teknik Informatika (PSTI) Fakultas Teknik Universitas Mataram. PKL adalah bentuk dari implementasi penguasaan keahlian yang didapatkan dalam bangku kuliah untuk diterapkan dalam dunia kerja untuk mencapai keahlian tertentu. Dengan pelaksanaan PKL tersebut, diharapkan PSTI mampu mencetak mahasiswa yang memiliki kompetensi lulusan yang dibutuhkan di dunia kerja.

Proses administrasi PKL pada PSTI masih dilakukan secara manual baik proses pendaftaran, pengajuan tempat, pengajuan topik sampai pendaftaran seminar hasil PKL. Berikut ini merupakan prosedur pengajuan dan pelaksanaan PKL pada program studi teknik informatika:

1. Mahasiswa mengisi formulir pendaftaran PKL di program studi dan akan memperoleh Surat Permohonan Tempat PKL dari Fakultas Teknik. Mekanisme pengiriman surat dapat disesuaikan dengan kebutuhan (dapat dikirim oleh pihak fakultas atau oleh mahasiswa yang bersangkutan).

2. Berdasarkan surat permohonan pada poin (1), instansi/perusahaan akan mengirimkan balasan ke fakultas.

3. Apabila disetujui, salinan surat balasan dari instansi/perusahaan akan diteruskan ke pihak program studi.

4. Pihak program studi akan melakukan penunjukan Dosen Pembimbing, memberikan Lembar Konsultasi PKL untuk mencatat aktivitas ketika berkonsultasi dengan Dosen Pembimbing dan Lembar Log Harian untuk mencatat aktivitas harian yang dilakukan di tempat PKL.

5. Topik PKL dikonsultasikan dengan Dosen Pembimbing sebelum melakukan aktivitas PKL di instansi/perusahaan. Pelaksanaan PKL seorang mahasiswa di suatu lokasi hanya dianggap sah apabila mahasiswa telah memperoleh persetujuan dosen pembimbing PKL perihal topik PKL yang boleh dikerjakan di lokasi tersebut. Oleh karena itu, mahasiswa 
diwajibkan berdiskusi dengan dosen pembimbing PKL perihal topik PKL sebelum PKL dilaksanakan.

Proses administrasi PKL pada PSTI yang masih dilakukan secara manual tentunya membutuhkan waktu yang lama karena banyaknya mahasiswa yang ingin melaksanakan PKL sehingga pelayanan administrasi pada PKL menjadi tidak efektif. Selain itu terdapat beberapa masalah lain di antaranya:

1. Kesulitan ketua program studi dalam menentukan dosen pembimbing secara merata yang sesuai dengan bidang keahlian dosen.

2. Sistem bimbingan atau konsultasi mahasiswa kepada dosen masih dilakukan secara manual. Hal ini sering kali menjadi masalah ketika dosen yang bersangkutan memiliki kesibukan dan sulit ditemui atau mahasiswa melakukan PKL di luar kota.

3. Penerapan sistem yang masih manual menyulitkan dosen pembimbing dalam memonitor perkembangan mahasiswa bimbingannya.

Berdasarkan uraian di atas maka perlu adanya suatu sistem informasi yaitu sistem informasi PKL yang ditujukan untuk membantu pelaksanaan administrasi PKL seperti proses pengajuan $\mathrm{PKL}$, pengajuan dosen pembimbing PKL, bimbingan PKL, pengajuan seminar hasil PKL dan proses pemantauan mahasiswa yang melaksanakan PKL oleh dosen ataupun staf program studi.

\section{TINJAUAN PUSTAKA}

Penelitian mengenai sistem informasi praktik kerja lapangan sudah dilakukan[1] dengan judul "Rancang Bangun Sistem Informasi Praktik Kerja Lapangan Berbasis Web dengan Metode Waterfall'. Penelitian ini ditujukan untuk membantu penyelesaian beberapa kendala yang dihadapi oleh pihak-pihak terkait pelaksanaan PKL.

Penelitian lain yang dilakukan[2] yang berjudul "Sistem Informasi Praktik Kerja Lapangan Pada Jurusan D-3 Ilmu Komputer Departemen Matematika Universitas Sumatra Utara”. Penelitian ini bertujuan untuk memudahkan pengelolaan data PKL pada D-3 Ilmu Komputer Universitas Sumatra Utara. Proses yang dapat dilakukan dalam sistem ini mulai dari proses pengajuan PKL serta proses penilaian hasil PKL mahasiswa.

Penelitian lain adalah penelitian dengan judul “Analisa dan Perancangan Sistem Informasi Praktik kerja Lapangan pada Instansi/Perusahaan"[3] Dalam penelitian ini bagian yang diteliti adalah sistem informasi praktik kerja lapangan pada perusahaan tempat mahasiswa melaksanakan PKL.

\section{Exterme Programming}

Menurut[4] Extreme programing adalah disiplin pengembangan perangkat lunak yang menekankan pada produktivitas, fleksibilitas, informalitas, kerja sama tim, dan penggunaan teknologi yang terbatas di luar pemrograman.

Extreme Programming memiliki kerangka kerja yang terbagi menjadi empat konteks aktivitas utama. Empat konteks tersebut adalah Planning, Design, Coding dan Testing. Keempat aktivitas inilah yang akan menghasilkan sebuah perangkat lunak yang didasari dengan konsep model Extreme Programming.

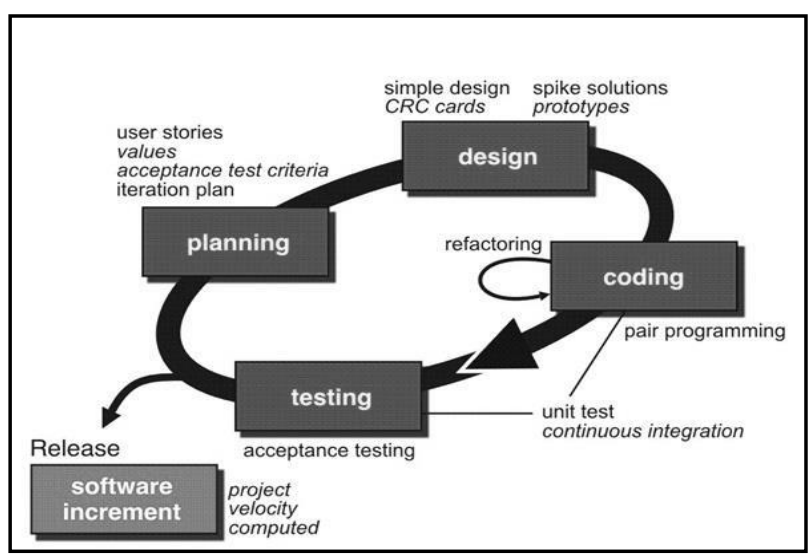

Gambar 1 : Kerangka kerja extreme programming [5]

\section{a) Planning}

Planning berfokus untuk mendapatkan gambaran fitur dan fungsi dari perangkat lunak yang akan dibangun. Aktivitas planning dimulai dengan membuat kumpulan gambaran atau cerita yang telah diberikan oleh klien yang akan menjadi gambaran dasar dari perangkat lunak tersebut. Kumpulan gambaran atau cerita tersebut akan dikumpulkan dalam sebuah indeks di mana setiap poin memiliki prioritasnya masing-masing.

b) Design

Aktivitas design dalam pengembangan aplikasi ini, bertujuan untuk mengatur pola logika dalam sistem. Sebuah desain aplikasi yang baik adalah desain yang dapat mengurangi ketergantungan antar setiap proses pada sebuah sistem. Jika salah satu fitur pada sistem mengalami kerusakan, maka hal tersebut tidak akan mempengaruhi sistem secara keseluruhan.

c) Coding 
Setelah menyelesaikan gambaran dasar perangkat lunak dan menyelesaikan design untuk aplikasi secara keseluruhan, XP lebih merekomendasikan tim untuk membuat modul unit tes terlebih dahulu yang bertujuan untuk melakukan uji coba setiap cerita dan gambaran yang diberikan oleh klien. Setelah berbagai unit tes selesai dibangun, tim barulah melanjutkan aktivitasnya ke penulisan coding aplikasi. XP menerapkan konsep Pair Programming di mana setiap tugas sebuah modul dikembangkan oleh dua orang programmer.

\section{d) Testing}

Walaupun tahapan uji coba sudah dilakukan pada tahapan coding, XP juga akan melakukan pengujian sistem yang sudah sempurna. Pada tahap coding, XP akan terus mengecek dan memperbaiki semua masalah-masalah yang terjadi walaupun hanya masalah kecil. Setiap modul yang sedang dikembangkan, akan diuji terlebih dahulu dengan modul unit tes yang telah dibuat sebelumnya.

\section{METODE PENELITIAN}

Pada tahapan ini dilakukan penggalian informasi dengan menggunakan metode wawancara untuk mendapatkan informasi (user stories) yang valid terkait dengan sistem yang dibangun. Informasi (user stories) tersebut diringkas seperti yang ditujukan pada Tabel 3.1 berikut.

\section{Planning}

TABLE I. USER STORIES SISTEM INFORMASI PKL

\begin{tabular}{|c|c|c|c|}
\hline No & Sebagai & $\begin{array}{c}\text { Dapat } \\
\text { melakukan }\end{array}$ & Sehingga \\
\hline 1. & Mahasiswa & Login & $\begin{array}{lr}\text { Masuk } & \text { dalam } \\
\text { sistem } & \text { informasi } \\
\text { PKL } & \end{array}$ \\
\hline 2. & Mahasiswa & Logout & $\begin{array}{l}\text { Keluar dari sistem } \\
\text { informasi PKL }\end{array}$ \\
\hline 3. & Mahasiswa & $\begin{array}{l}\text { Mengajuka } \\
\mathrm{n} \text { PKL }\end{array}$ & Melaksanakan PKL \\
\hline 4. & Mahasiswa & $\begin{array}{l}\text { Mengisi } \\
\text { data PKL }\end{array}$ & $\begin{array}{l}\text { Mendapatkan dosen } \\
\text { pembimbing }\end{array}$ \\
\hline 5. & Mahasiswa & $\begin{array}{l}\text { Mengubah } \\
\text { data PKL }\end{array}$ & $\begin{array}{ll}\text { Mengubah } & \text { judul } \\
\text { dan mengisi nama } & \text { nembimbing } \\
\text { pemangan } & \\
\text { lapangan }\end{array}$ \\
\hline 6. & Mahasiswa & $\begin{array}{l}\text { Mengisi log } \\
\text { harian }\end{array}$ & $\begin{array}{l}\text { Mahasiswa dapat } \\
\text { dipantau log harian } \\
\text { mahasiswa oleh } \\
\text { dosen, staf, ketua } \\
\text { program studi dan } \\
\text { instansi atau } \\
\text { perusahaan }\end{array}$ \\
\hline 7. & Mahasiswa & $\begin{array}{l}\text { Bimbingan } \\
\text { PKL }\end{array}$ & \begin{tabular}{lr}
\multicolumn{2}{l}{ Mendapatkan } \\
verifikasi & selesai \\
bimbingan & dari \\
dosen &
\end{tabular} \\
\hline 8. & Mahasiswa & $\begin{array}{l}\text { Mendaftar } \\
\text { Seminar }\end{array}$ & $\begin{array}{l}\text { Dapat melakukan } \\
\text { seminar hasil PKL }\end{array}$ \\
\hline
\end{tabular}

\begin{tabular}{|c|c|c|c|}
\hline 9. & Mahasiswa & $\begin{array}{l}\text { Menggugah } \\
\text { Jurnal }\end{array}$ & Dapat Melihat Nilai \\
\hline 10. & Mahasiswa & $\begin{array}{l}\text { Melihat } \\
\text { nilai PKL }\end{array}$ & $\begin{array}{l}\text { Dapat melihat hasil } \\
\text { PKL yang telah } \\
\text { dilakukan }\end{array}$ \\
\hline 11. & $\begin{array}{l}\text { Staf program } \\
\text { studi }\end{array}$ & Login & $\begin{array}{lr}\text { Masuk } & \text { dalam } \\
\text { sistem } & \text { informasi } \\
\text { PKL } & \end{array}$ \\
\hline 12. & $\begin{array}{l}\text { Staf program } \\
\text { studi }\end{array}$ & Logout & $\begin{array}{l}\text { Keluar dari sistem } \\
\text { informasi PKL }\end{array}$ \\
\hline 13. & $\begin{array}{l}\text { Staf program } \\
\text { studi }\end{array}$ & $\begin{array}{l}\text { Mengelola } \\
\text { data } u \text { ser }\end{array}$ & $\begin{array}{l}\text { Dapat menambah, } \\
\text { mengubah dan } \\
\text { menghapus data } \\
\text { user }\end{array}$ \\
\hline 14. & $\begin{array}{l}\text { Staf } \\
\text { studi }\end{array}$ & $\begin{array}{l}\text { Mengelola } \\
\text { data } \\
\text { mahasiswa }\end{array}$ & $\begin{array}{lr}\text { Dapat menambah, } \\
\text { mengubah dan } \\
\text { menghapus } \\
\text { mahasiswa }\end{array}$ \\
\hline 15. & $\begin{array}{l}\text { Staf program } \\
\text { studi }\end{array}$ & $\begin{array}{l}\text { Mengelola } \\
\text { data dosen }\end{array}$ & $\begin{array}{lr}\text { Dapat menambah, } \\
\text { mengubah dan } \\
\text { menghapus data } \\
\text { dosen }\end{array}$ \\
\hline 16. & $\begin{array}{l}\text { Staf program } \\
\text { studi }\end{array}$ & $\begin{array}{l}\text { Mengelola } \\
\text { data } \\
\text { instansi }\end{array}$ & $\begin{array}{lr}\text { Dapat menambah, } \\
\text { mengubah dan } \\
\text { menghapus data } \\
\text { instansi }\end{array}$ \\
\hline 17. & $\begin{array}{l}\text { Staf program } \\
\text { studi }\end{array}$ & $\begin{array}{l}\text { Menambah } \\
\text { kan data } \\
\text { mahasiswa } \\
\text { yang } \\
\text { mengambil } \\
\text { mata kuliah } \\
\text { PKL }\end{array}$ & $\begin{array}{l}\text { Mahasiswa dapat } \\
\text { mendaftar atau } \\
\text { mengajukan PKL. }\end{array}$ \\
\hline 18. & $\begin{array}{l}\text { Staf } \\
\text { studi }\end{array}$ & $\begin{array}{l}\text { Melihat } \\
\text { pendaftar } \\
\text { PKL }\end{array}$ & $\begin{array}{l}\text { Dapat } \\
\text { memverifikasi data } \\
\text { daftar PKL dan } \\
\text { mencetak surat } \\
\text { pengantar PKL } \\
\text { untuk mahasiswa. }\end{array}$ \\
\hline 19. & $\begin{array}{l}\text { Staf } \\
\text { studi }\end{array}$ & $\begin{array}{l}\text { Verifikasi } \\
\text { data } \\
\text { pendaftar }\end{array}$ & $\begin{array}{l}\text { Mahasiswa dapat } \\
\text { melakukan PKL }\end{array}$ \\
\hline 20. & $\begin{array}{l}\text { Staf program } \\
\text { studi }\end{array}$ & $\begin{array}{l}\text { Cetak surat } \\
\text { pengantar } \\
\text { PKL }\end{array}$ & $\begin{array}{l}\text { Mahasiswa dapat } \\
\text { mengajukan PKL } \\
\text { pada instansi atau } \\
\text { perusahaan }\end{array}$ \\
\hline 21. & $\begin{array}{ll}\begin{array}{l}\text { Staf } \\
\text { studi }\end{array} & \text { program } \\
\end{array}$ & $\begin{array}{l}\text { Kelola data } \\
\text { PKL }\end{array}$ & $\begin{array}{l}\text { Dapat melihat data } \\
\text { PKL mahasiswa }\end{array}$ \\
\hline 22. & $\begin{array}{l}\text { Staf program } \\
\text { studi }\end{array}$ & $\begin{array}{l}\text { Cetak surat } \\
\text { tugas }\end{array}$ & $\begin{array}{lr}\text { Dosen } & \text { dapat } \\
\text { membimbing } & \text { PKL } \\
\text { mahasiswa } & \\
\end{array}$ \\
\hline 23. & $\begin{array}{l}\text { Staf program } \\
\text { studi }\end{array}$ & $\begin{array}{l}\text { Melihat } \\
\text { timeline } \\
\text { PKL } \\
\text { mahasiswa }\end{array}$ & $\begin{array}{l}\text { Dapat memantau } \\
\text { perkembangan PKL } \\
\text { mahasiswa }\end{array}$ \\
\hline 24. & $\begin{array}{l}\text { Staf program } \\
\text { studi }\end{array}$ & $\begin{array}{l}\text { Melihat } \\
\text { pendaftar } \\
\text { seminar }\end{array}$ & $\begin{array}{l}\text { Dapat menentukan } \\
\text { ruangan seminar } \\
\text { dan mencetak berita } \\
\text { acara seminar }\end{array}$ \\
\hline 25 . & $\begin{array}{l}\text { Ketua program } \\
\text { studi }\end{array}$ & Login & $\begin{array}{l}\text { Dapat masuk dalam } \\
\text { sistem }\end{array}$ \\
\hline 26. & $\begin{array}{l}\text { Ketua } \\
\text { program studi }\end{array}$ & $\begin{array}{l}\text { Melihat } \\
\text { data PKL }\end{array}$ & $\begin{array}{l}\text { Menentukan dosen } \\
\text { Pembimbing }\end{array}$ \\
\hline 27. & $\begin{array}{l}\text { Ketua program } \\
\text { studi }\end{array}$ & $\begin{array}{l}\text { Melihat } \\
\text { jumlah } \\
\text { bimbingan } \\
\text { dosen }\end{array}$ & $\begin{array}{lr}\text { Melihat } & \text { berapa } \\
\text { banyak jumlah } \\
\text { mahasiswa yang } \\
\text { dibimbing oleh satu } \\
\text { dosen }\end{array}$ \\
\hline 28. & $\begin{array}{l}\text { Ketua program } \\
\text { studi }\end{array}$ & $\begin{array}{l}\text { Menentuka } \\
\mathrm{n} \text { dosen } \\
\text { Pembimbin } \\
\mathrm{g}\end{array}$ & $\begin{array}{l}\text { Dapat menentukan } \\
\text { dosen yang harus } \\
\text { membimbing } \\
\text { mahasiswa dalam } \\
\text { pelaksanaan PKL. }\end{array}$ \\
\hline
\end{tabular}




\begin{tabular}{|c|c|c|c|}
\hline 29. & $\begin{array}{l}\text { Ketua program } \\
\text { studi }\end{array}$ & $\begin{array}{l}\text { Melihat } \\
\text { data PKL }\end{array}$ & $\begin{array}{l}\text { Dapat melihat data } \\
\text { PKL dan memantau } \\
\text { perkembangan PKL } \\
\text { mahasiswa }\end{array}$ \\
\hline 30. & $\begin{array}{l}\text { Ketua program } \\
\text { studi }\end{array}$ & $\begin{array}{l}\text { Melihat } \\
\text { pelaporan } \\
\text { PKL }\end{array}$ & $\begin{array}{l}\text { Dapat melihat data } \\
\text { PKL mahasiswa } \\
\text { yang sudah selesai } \\
\text { dan belum selesai } \\
\text { melaksanakan PKL }\end{array}$ \\
\hline 31. & Dosen & Login & $\begin{array}{lr}\text { Masuk } & \text { dalam } \\
\text { sistem } & \text { informasi } \\
\text { PKL } & \end{array}$ \\
\hline 32. & Dosen & $\begin{array}{l}\text { Melihat } \\
\text { jumlah } \\
\text { bimbingan }\end{array}$ & $\begin{array}{lr}\text { Melihat } & \text { berapa } \\
\text { banyak } & \text { jumlah } \\
\text { mahasiswa } & \text { yang } \\
\text { dibimbing } & \text { dan } \\
\text { mengetahui } & \text { jumlah } \\
\text { bimbingan } & \text { yang } \\
\text { telah } & \text { selesai } \\
\text { melakukan } & \text { PKL } \\
\text { atau belum } & \\
\end{array}$ \\
\hline 33. & Dosen & $\begin{array}{l}\text { Melihat } \\
\text { data PKL, } \\
\text { Log harian } \\
\text { dan } \\
\text { timeline } \\
\text { PKL }\end{array}$ & $\begin{array}{l}\text { Memantau } \\
\text { perkembangan PKL } \\
\text { mahasiswa } \\
\text { bimbingannya. }\end{array}$ \\
\hline 34. & Dosen & $\begin{array}{l}\text { Membimbi } \\
\text { ng } \\
\text { mahasiswa }\end{array}$ & $\begin{array}{l}\text { Dosen dapat } \\
\text { melihat } \\
\text { perkembangan } \\
\text { laporan mahasiswa. }\end{array}$ \\
\hline 35. & Dosen & $\begin{array}{l}\text { Menginput } \\
\text { nilai }\end{array}$ & $\begin{array}{l}\text { Memberikan nilai } \\
\text { pada mahasiswa } \\
\text { bimbingannya. }\end{array}$ \\
\hline 36. & Dosen & $\begin{array}{l}\text { verifikasi } \\
\text { pendaftaran } \\
\text { seminar }\end{array}$ & $\begin{array}{l}\text { Mahasiswa dapat } \\
\text { melakukan seminar }\end{array}$ \\
\hline 37. & Dosen & $\begin{array}{l}\text { Melihat } \\
\text { jadwal } \\
\text { seminar }\end{array}$ & $\begin{array}{lr}\text { Dapat } & \text { melihat } \\
\text { jadwal } & \text { seminar } \\
\text { PKL mahasiswa. }\end{array}$ \\
\hline 38. & $\begin{array}{l}\text { Perusahaan atau } \\
\text { instansi }\end{array}$ & Login & $\begin{array}{lr}\text { Masuk } & \text { dalam } \\
\text { sistem } & \text { informasi } \\
\text { PKL } & \end{array}$ \\
\hline 39. & $\begin{array}{l}\text { Perusahaan atau } \\
\text { instansi }\end{array}$ & $\begin{array}{l}\text { Melihat } \\
\text { data PKL } \\
\text { dan Log } \\
\text { harian } \\
\text { mahasiswa }\end{array}$ & $\begin{array}{l}\text { Melihat } \\
\text { perkembangan } \\
\text { mahasiswa yang } \\
\text { melaksanakan PKL } \\
\text { pada tempatnya }\end{array}$ \\
\hline 40. & $\begin{array}{l}\text { Perusahaan atau } \\
\text { instansi }\end{array}$ & $\begin{array}{l}\text { Input nilai } \\
\text { PKL }\end{array}$ & $\begin{array}{l}\text { Memberikan nilai } \\
\text { hasil PKL kepada } \\
\text { mahasiswa }\end{array}$ \\
\hline 41. & $\begin{array}{l}\text { Perusahaan atau } \\
\text { instansi }\end{array}$ & $\begin{array}{l}\text { Upadate } \\
\text { data } \\
\text { instansi } \\
\text { atau } \\
\text { perusahaan }\end{array}$ & $\begin{array}{l}\text { Dapat mengubah } \\
\text { data instansi atau } \\
\text { perusahaan terkait. }\end{array}$ \\
\hline
\end{tabular}

Dari tabel user stories yang ditujukan pada TABEL I akan diurutkan dan dikerjakan sesuai dengan prioritasnya, di mana urutan prioritas ditentukan berdasarkan alur kerja PKL yang sudah ada. User stories di atas akan dibuat menjadi rencana rilis sistem yang akan dibagi menjadi beberapa rilis di mana pembagiannya sesuai dengan urutan tahapan dalam proses PKL tersebut. Berikut merupakan rencana rilis sistem yang dikembangkan

TABLE II. RENCANA RILIS Ke-1

\begin{tabular}{|l|l|l|l|}
\hline \multirow{2}{*}{ No } & \multirow{2}{*}{ Topik umum fungsi } & \multicolumn{2}{|c|}{ Iterasi } \\
\cline { 3 - 4 } & I & II \\
\hline
\end{tabular}

\begin{tabular}{|c|l|c|c|}
\hline 1 & Login (Mahasiswa, Staf, Kaprodi ) & $\checkmark$ & \\
\hline 2 & Logout (Mahasiswa, Staf, Kaprodi) & $\checkmark$ & \\
\hline 3 & $\begin{array}{l}\text { Pengelolaan data diri mahasiswa } \\
\text { (Mahasiswa) }\end{array}$ & $\checkmark$ & \\
\hline 4 & Pengelolaan data mahasiswa (Staf) & $\checkmark$ & \\
\hline 5 & Pengelolaan data dosen (Staf) & $\checkmark$ & \\
\hline 6 & Pengelolaan data instansi(Staf) & $\checkmark$ & \\
\hline 7 & Revisi I & & $\checkmark$ \\
\hline 8 & Input KRS PKL mahasiswa (Staf) & & $\checkmark$ \\
\hline 9 & $\begin{array}{l}\text { Pendaftaran / pengajuan PKL } \\
\text { (Mahasiswa) dan Pendaftar PKL }\end{array}$ & & $\checkmark$ \\
\hline 10 & $\begin{array}{l}\text { Pengelolaan data } \\
\text { (Staf) }\end{array}$ & $\checkmark$ \\
\hline 11 & Pengajuan topik PKL (Mahasiswa) & & $\checkmark$ \\
\hline 12 & $\begin{array}{l}\text { Penentuan dosen pembimbing PKL } \\
\text { (Kaprodi) }\end{array}$ & & $\checkmark$ \\
\hline 13 & $\begin{array}{l}\text { Pengelolaan data PKL mahasiswa } \\
\text { (Staf) }\end{array}$ & & $\checkmark$ \\
\hline
\end{tabular}

TABLE III. RENCANA RILIS Ke-2

\begin{tabular}{|c|c|c|c|}
\hline No & Topik umum fungsi & \multicolumn{2}{|c|}{ Iterasi } \\
\hline 1 & Login (Dosen) & $\checkmark$ & \\
\hline 2 & Logout (Dosen) & $\checkmark$ & \\
\hline 3 & $\begin{array}{l}\text { Lihat data mahasiswa bimbingan } \\
\text { (Dosen) }\end{array}$ & $\checkmark$ & \\
\hline 4 & $\begin{array}{l}\text { Lihat timeline } \\
\text { bimbingan (Dosen) }\end{array}$ & $\checkmark$ & \\
\hline 5 & Konsultasi laporan (Mahasiswa) & $\checkmark$ & \\
\hline 6 & $\begin{array}{lll}\text { Lihat dan } & \text { isi } & \text { riwayat } \\
\text { konsultasi(Dosen) } & & \end{array}$ & $\checkmark$ & \\
\hline 7 & Mendaftar seminar (Mahasiswa) & $\checkmark$ & \\
\hline 8 & Verifikasi seminar (Dosen) & $\checkmark$ & \\
\hline 9 & Penentuan ruangan seminar (staf) & $\checkmark$ & \\
\hline 10 & $\begin{array}{l}\text { Lihat jadwal seminar (Dosen dan } \\
\text { mahasiswa) }\end{array}$ & $\checkmark$ & \\
\hline 11 & Revisi & & $\checkmark$ \\
\hline 12 & Login (Instansi) & & $\checkmark$ \\
\hline 13 & Logout (Instansi) & & $\checkmark$ \\
\hline 14 & $\begin{array}{l}\text { Lihat data mahasiswa } \\
\text { (Instansi) }\end{array}$ & & $\checkmark$ \\
\hline 15 & Lihat log harian (Instansi) & & $\sqrt{ }$ \\
\hline 16 & Lihat nilai lapangan (Instansi) & & $\checkmark$ \\
\hline 17 & Input nilai lapangan (Instansi) & & $\checkmark$ \\
\hline 18 & Lihat nilai dosen (Dosen) & & $\checkmark$ \\
\hline 19 & Input nilai dosen (Dosen) & & $\checkmark$ \\
\hline 20 & Unggah jurnal PKL (Mahasiswa) & & $\checkmark$ \\
\hline 21 & Verifikasi jurnal (Staf) & & $\checkmark$ \\
\hline 22 & Lihat nilai (Mahasiswa) & & $\checkmark$ \\
\hline 23 & Lihat nilai (staf) & & $\checkmark$ \\
\hline 24 & Export nilai (staf) & & $\checkmark$ \\
\hline 25 & Lihat pelaporan (Kaprodi) & & $\checkmark$ \\
\hline
\end{tabular}

\section{Design}

Di bawah ini merupakan design use case diagram dari sistem informasi PKL dari masingmasing iterasi pada setiap rilis. Use case merupakan penggambaran fungsionalitas dari setiap pengguna dalam menjalankan sistem.

\section{Uase case diagram rilis pertama iterasi I}

Terdapat satu actor yaitu staf di mana staf dapat melakukan login kemudian setelah login akan dilakukan validasi apakah staf sudah terdaftar atau tidak pada sistem. Apabila terdaftar maka staf dapat melakukan kelola data user, kelola data mahasiswa, kelola data dosen dan kelola data instansi seperti 
yang ditujukan pada use case yang ditujukan pada Gambar 2.

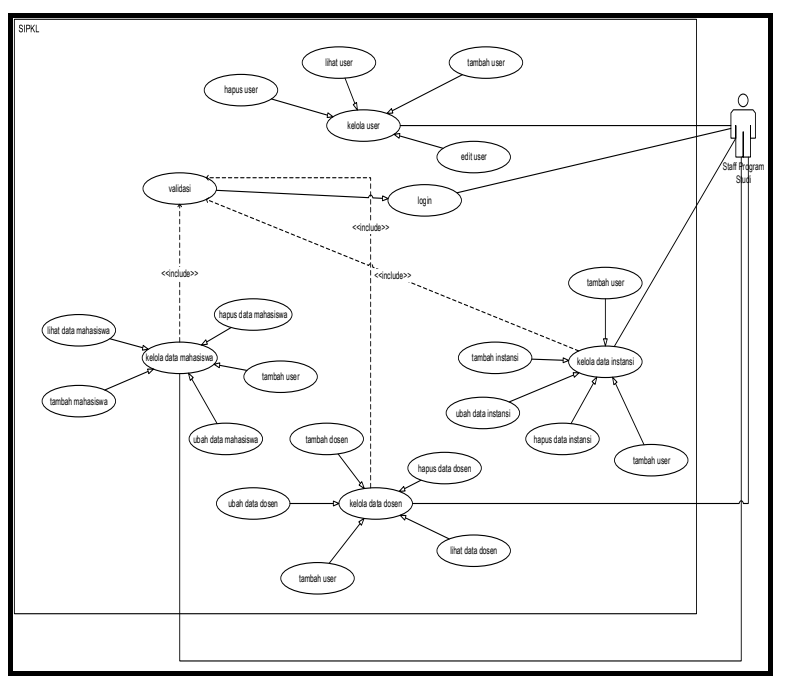

Gambar 2 Use Case Diagram Rilis Pertama Iterasi I

\section{Use case diagram rilis pertama iterasi I}

Terdapat tiga actor yaitu staf, ketua program studi dan mahasiswa seperti yang ditujukan pada Gambar 3. Pada bagian ini ditambahkan fasilitas pengelolaan data PKL bagi mahasiswa, melihat data PKL dan melihat rekap jumlah bimbingan bagi ketua program studi, serta melengkapi fasilitas pengelolaan data PKL bagi staf program studi. Dalam iterasi ini juga ditambahkan fasilitas mencetak surat pengantar, memverifikasi pendaftar, melihat data pendaftar PKL, mencetak surat tugas, dan mendaftarkan KRS PKL untuk staf program studi yang bertugas melayani PKL mahasiswa.

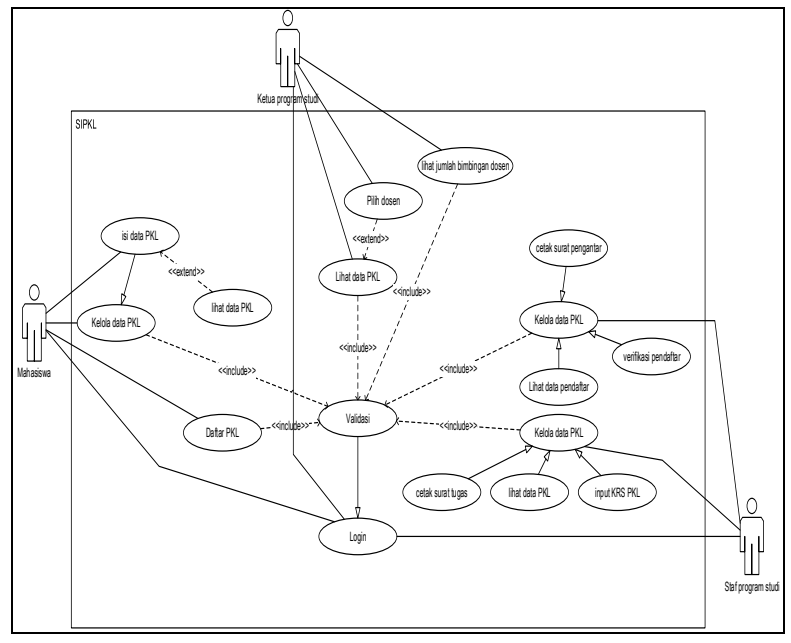

3. Use case diagram rilis ke dua iterasi I

Terdapat tiga actor dalam use case ini antara lain Mahasiswa, Dosen dan Staf seperti yang Gambar 3 Use case diagram rilis pertama iterasi II ditujukan pada Gambar 4. Pada rilis kedua ditambahkan fasilitas bagi mahasiswa berupa melihat data seminar mengisi log harian, mengisi bimbingan/konsultasi. Fasilitas bagi dosen berupa mengelola seminar, mengelola bimbingan, dan mengelola data mahasiswa bimbingan. Bagi ketua program studi dapat melihat timeline proses PKL mahasiswa pada proses kelola data PKL. Bagi staf program studi dapat juga melihat timeline mahasiswa, mengelola seminar, mencetak berita acara dan menentukan ruangan seminar PKL.

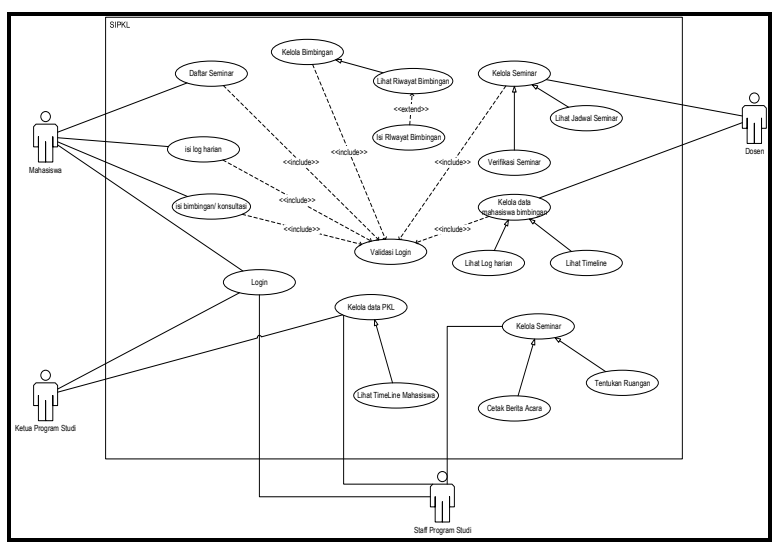

Gambar 4 Use case diagram rilis ke dua iterasi I

\section{Use case diagram rilis ke dua iterasi II}

Terdapat beberapa actor yang digambarkan seperti staf, ketua program studi, mahasiswa, dosen dan instansi. Pada iterasi ini mahasiswa memperoleh fasilitas mengunggah jurnal dan melihat nilai hasil PKL. Bagi instansi perusahaan ditambahkan fasilitas berupa mengelola/membaca log harian, mengisikan tugas, dan memperbarui data instansi. Bagi dosen disediakan fasilitas melihat dan mengisikan nilai akhir PKL mahasiswa. Ketua program studi ditambahkan fasilitas melihat laporan. Fasilitas melihat nilai dan mengekspor nilai ditambahkan untuk staf program studi.

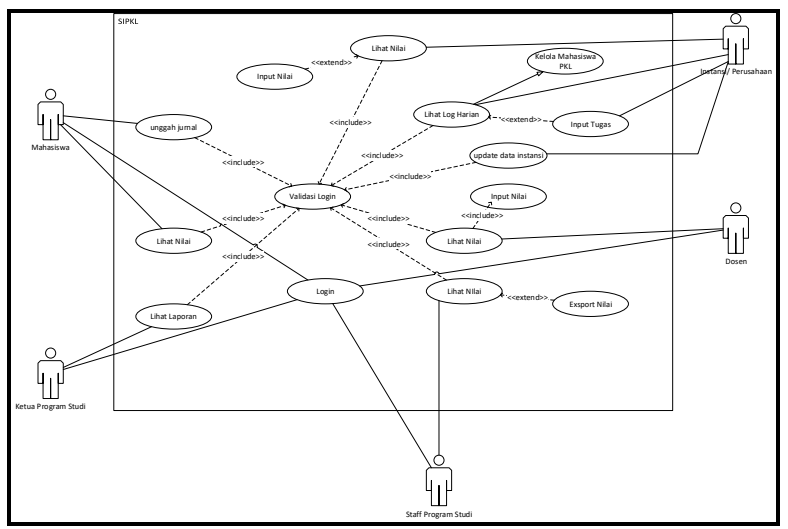

Gambar 5 Use case diagram rilis ke dua iterasi II 


\section{HASIL DAN PEMBAHASAN}

Berikut merupakan hasil dari implementasi interface yang telah di desain berdasarkan iterasi tiap-tiap rilis.

A. Implementasi rilis pertama iterasi I

Di bawah ini merupakan hasil implementasi interface dari rilis pertama iterasi I.

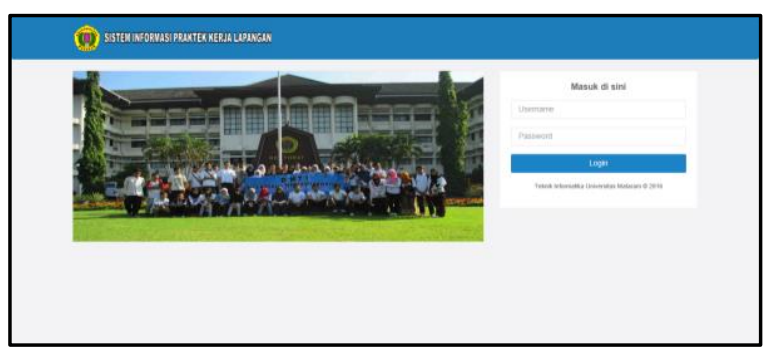

Gambar 6 Interface halaman depan sistem informasi PKL

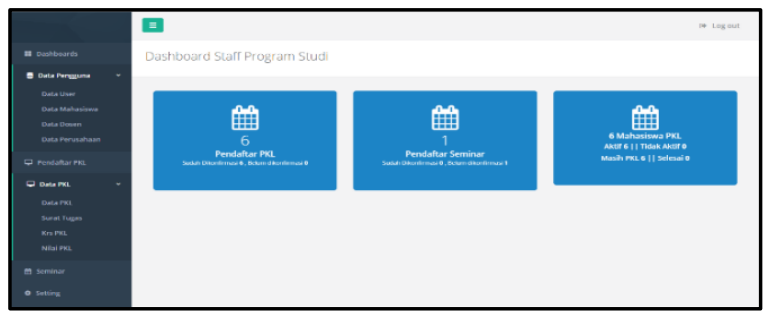

Gambar 7 Interface halaman utama staf.

B. Implementasi rilis pertama iterasi II

Di bawah ini merupakan hasil implementasi interface dari rilis pertama iterasi II.

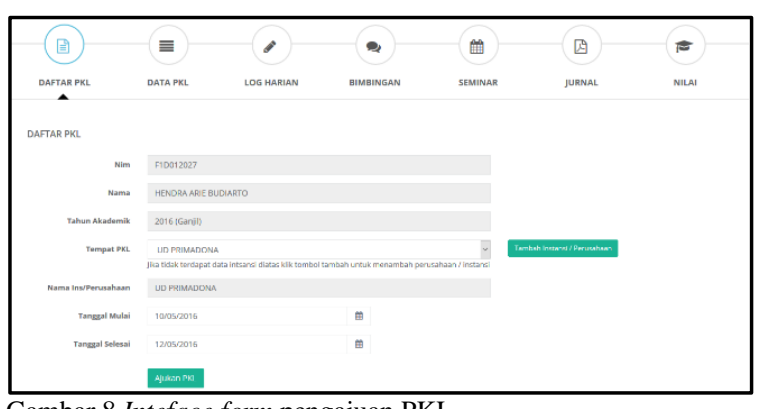

Gambar 8 Inteface form pengajuan PKL

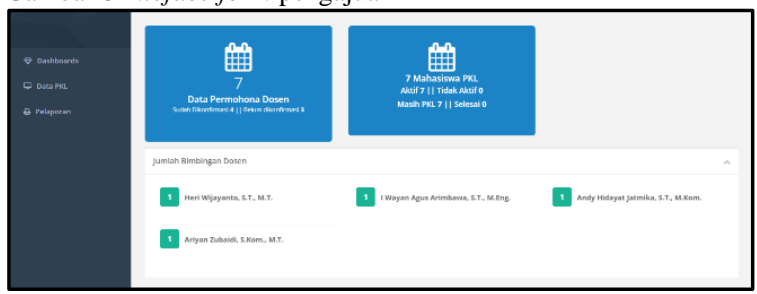

Gambar 9 Interface halaman utama kaprodi

C. Implementasi rilis ke dua iterasi I

Berikut merupakan hasil implementasi interface dari rilis ke dua iterasi I.

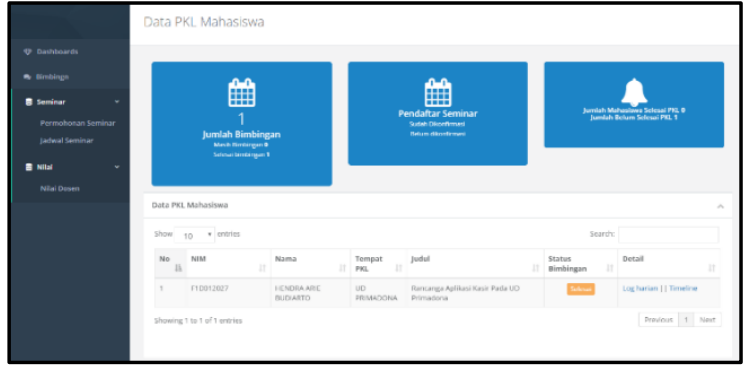

Gambar 10 Tampilan halaman depan dosen.

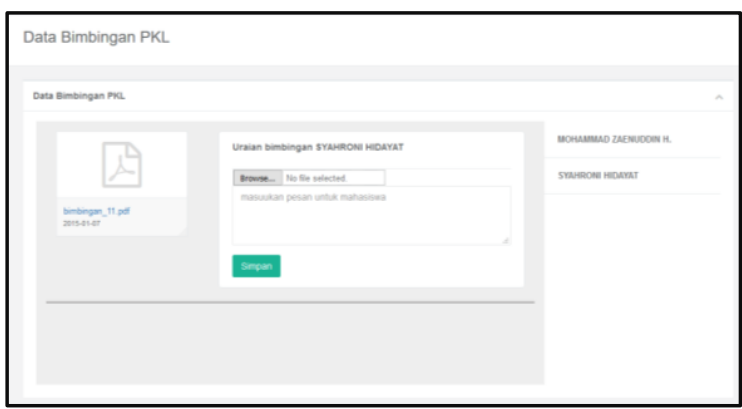

Gambar 11 Tampilan bimbingan pada dosen.

D. Implementasi rilis ke dua iterasi II

Di bawah ini merupakan hasil implementasi interface dari rilis ke dua iterasi II.

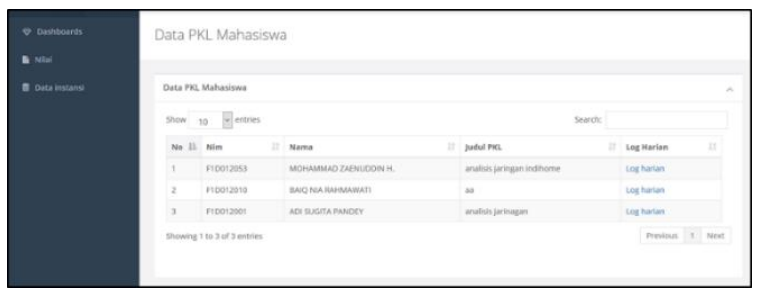

Gambar 12 Interface halaman halaman depan instansi atau perusahaan.

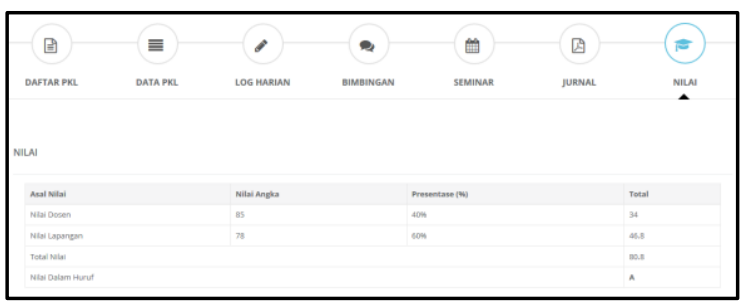

Gambar 4.8 Tampilan nilai pada mahasiswa.

\section{E. Testing}

Testing pada extreme programing dilakukan setelah tahap implementasi atau coding selesai dilakukan. Tahap ini dilakukan mengetahui apakah sudah sesuai dengan harapan atau tidak. Dalam sistem ini metode testing yang digunakan adalah User Aceptance Test (UAT) yang merupakan suatu proses uji untuk memenuhi sistem yang dikembangkan dapat diterima oleh pengguna. Pengujian menunjukkan semua fasilitas yang direncanakan telah disetujui oleh pengguna. 


\section{KESIMPULAN DAN SARAN}

A. Kesimpulan

Berdasarkan hasil pembahasan dan pengujian sistem yang dibuat maka dapat diambil kesimpulan sebagai berikut:

1. Sistem informasi PKL yang dibuat dapat digunakan mahasiswa untuk mendaftar PKL, mengisi log harian, melakukan bimbingan dan mendaftar seminar.

2. Sistem informasi PKL yang dibuat dapat digunakan staf untuk mengelola data pendaftar PKL, memantau perkembangan PKL mahasiswa, mengelola data pendaftar seminar PKL dan melihat nilai PKL mahasiswa.

3. Sistem informasi PKL ini dapat memudahkan ketua program studi menentukan dosen pembimbing PKL mahasiswa sesuai dengan bidang dan keahlian yang dimiliki oleh dosen.

4. Sistem informasi PKL dapat menampilkan perkembangan PKL mahasiswa sehingga staf, ketua program studi dan dosen dapat memantau perkembangan mahasiswa PKL.

5. Extreme programming tidak membutuhkan tim yang besar, rancangan yang komperhenship, tetapi lebih menekankan pada user story dan coding yang dilakukan bertahap sehingga waktu pengembangan sistem menjadi lebih singkat.

6. Extreme programming mengakomodir perubahan sistem yang diajukan oleh owner (pemilik project) karena perubahan akan selalu ada selama pengembangan sistem berlangsung.

7. Berdasarkan hasil pengujian dengan metode User Accaptance Test yang diujikan pada 5 (lima) responden yang terdiri dosen, ketua program studi, staf program studi, mahasiswa dan kepala lab dapat disimpulkan bahwa fiturfitur pada sistem tersebut telah memenuhi kebutuhan sistem yang diusulkan.

B. Saran

Adapun saran yang dapat disampaikan untuk pengembangan sistem informasi PKL ini lebih lanjut adalah:

1. Mengintegrasikan sistem informasi PKL yang sudah dibuat dengan sistem informasi akademik yang sudah ada. Hal ini bertujuan untuk memudahkan pertukaran data seperti data diri mahasiswa, data mahasiswa yang mengambil mata kuliah PKL serta data nilai PKL mahasiswa.

2. Membuat notifikasi untuk mahasiswa untuk setiap proses PKL yang telah dilakukan seperti pendaftar PKL, pendaftaran seminar dan batas pelaksanaan dan bimbingan PKL.

\section{REFERENCES}

[1] Safitri, S.T., Supriyadi, D., 2015, Rancang Bangun Sistem Informasi Praktik Kerja Lapangan Berbasis Web dengan Metode Waterfall, Jurnal Infotel Vol.7 No.1. p. 69-74.

[2] Sinambela, A.S., 2008, Sistem Informasi Praktik Kerja Lapangan Pada Jurusan D-3 Ilmu Komputer Departemen Matematika Universitas Sumatra Utara, Departemen Matematika - Fakultas Matematika dan Ilmu Pengetahuan Alam, Universitas Sumatra Utara.

[3] Arifin, M., 2014, Analisa Dan Perancangan Sistem Informasi Praktik Kerja Lapangan Pada Instansi/Perusahaan, Jurnal SIMETRIS, Vol 5 No.1, p. 49-55.

[4] Macias, F., Holcombe, M., Gheorghe, M., 2003, A Formal Experiment Comparing Extreme Programming with Traditional Software Construction, Proceedings of the Fourth Mexican International Conference on Computer Science.

[5] http://www.slideshare.net/AhsanRahim1/agili ty-principles-agile-process-models 